\title{
Conditional Mutagenesis in Oligodendrocyte Lineage Cells
}

\author{
Sandra Goebbels and Klaus-Armin Nave
}

\begin{abstract}
Cell-type-specific gene targeting with the Cre/loxP system has become an indispensable technique in experimental neuroscience, particularly for the study of late-born glial cells that make myelin. A plethora of conditional mutants and Cre-expressing mouse lines is now available to the research community that allows laboratories to readily engage in in vivo analyses of oligodendrocytes and their precursor cells. This chapter summarizes concepts and strategies in targeting myelinating glial cells in mice for mutagenesis or imaging, and provides an overview of the most important Cre driver lines successfully used in this rapidly growing field.
\end{abstract}

Key words Transgenic mice, Cre, Cell-type-specific targeting, Oligodendrocyte, Myelin

\section{Introduction}

1.1 Genetics of Oligodendrocyte Lineage Cells
Mouse genetics has become a powerful technique to study oligodendrocyte function and myelination in vivo. Building on a rich body of work from the 1960s on naturally occurring mouse mutants with characteristic dysmyelinating phenotypes and illustrious names, such as jimpy, rumpshaker, shiverer, and quaking mice, oligodendrocyte and myelin research made early use of cDNA and genomic cloning techniques. This allowed researchers to work with genetically defined mouse mutants of cloned genes well before most other fields in the neuroscience. In the 1990s, the generation of targeted mutations in mice, by homologous genomic recombination and selection of correctly targeted embryonic stem (ES) cells [1] (schematically depicted in Fig. 1), became a revolutionary technique throughout biology, allowing the functional analysis of virtually any gene in vivo. Thus, a few years after its introduction as a technique [2], a plethora of newly cloned genes, predicted to be important for the development of oligodendrocyte lineage cells (OLC, in the following for oligodendrocyte precursor cells (OPC) and mature oligodendrocytes) and Schwann cells were successfully inactivated and their phenotypes dissected. Targeted genes 
a)

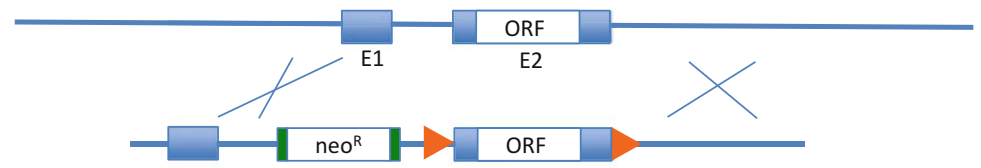

endogenous gene locus

targeting construct

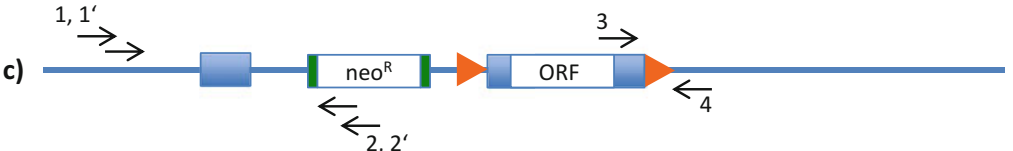

targeted locus after

homologousrec. in ESC

d)

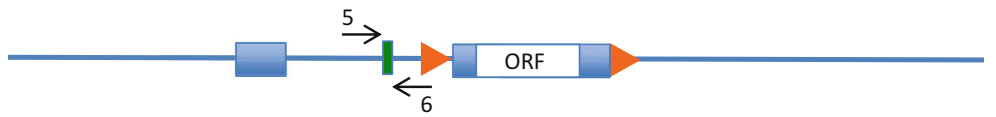

conditional allele

e)

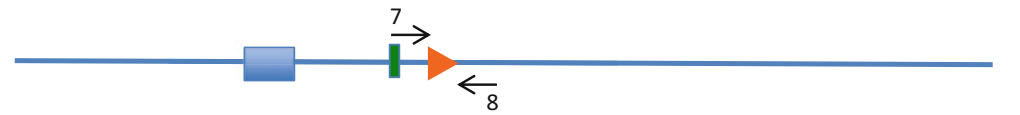

conditionally inactivated allele

Fig. 1 Scheme for conditional targeting of a gene in mice. (a) Simplified genomic structure of the wild-type allele. The locus comprises two exons (blue boxes E1 and E2) with the entire coding region (ORF) located within E2. (b) The targeting construct harbors a frt-flanked neo ${ }^{\mathrm{R}}$ selection cassette in intron 1 and the loxPflanked exon 2. Frt sites are depicted as green rectangles, loxP sites as orange triangles. (c) Modified allele after homologous recombination in ES cells. Homologous recombinants are identified by nested PCR using primers \#1 and \#2, and \#1' and \#2', respectively. Integration of the $3^{\prime}$ loxP site is independently demonstrated by PCR with primers \#3 and \#4. (d) Allele after deletion of the ne $0^{R}$ selection cassette. Breeding of targeted mice with Flp-deleter mice can lead to mosaic offspring. Presence of the selection cassette may be addressed with primers \#2 and \#5, absence of the ne $0^{R}$ cassette with primers \#5 and \#6. (e) Cell-type-specific ablation of the modified allele in mice is demonstrated by PCR using primers \#7 and \#8

\subsection{Principles of Conditional Mutagenesis in Mice}

included those for myelin-specific structural proteins, such as MPZ [3], PLPI [4], or CNP [5], and OLC-specific transcription factors, such as Olig 1 [6] or MYRF [7]. These added to the natural mouse mutants, often point mutations, for which gain- and loss-of-function effects were sometimes difficult to separate. Protocols for the positive/negative selection of mutant ES cells for germline transmission have been optimized [8] and the standard work flow in the authors' lab is detailed in $[4,9]$.

The ubiquitous inactivation of any widely expressed gene with a role in OLC can cause strong developmental defects and even early lethality in mice, which limits the value of "conventional" null mutants in the analysis of oligodendrocytes of the postnatal or adult nervous system. This is particularly true for genes whose knockouts die prematurely, such as the null mutants of the transcription factor (TF) genes Olig2 [10], Mrf [7], or SoxI0 [11] and in the majority of cases, in which the targeted gene has vital roles outside the oligodendroglial cell lineage. This is also the case for TF 
genes, such as Zfhxlb/Sipl [12], Үyl [13], or Hiflalpha [14], for specific micro-RNAs and their processing enzymes, and for genes encoding growth factors, their receptors, and downstream effectors in signaling cascades.

To circumvent these problems, sequence-specific recombination systems, such as the "Flp/frt" system (derived from Saccharomyces cerevisiae [15]) or the more widely utilized "Cre/loxP" system (derived from the bacteriophage Pl [16]), have been established that enable a spatially and temporally controlled modification of target genes. Cre, a $38 \mathrm{kD}$ cyclization recombinase, belongs to the integrase family of site-specific recombinases and catalyzes recombination at specific recognition sites, termed "loxP" sequences that comprise 2 palindromic 13 bp binding sites flanking a central asymmetric 8 bp "spacer region" (Fig. 2). The Cre/loxP technology can be used to carry out deletions, integrations, inversions, or translocations of double-stranded DNA fragments. However, the most widespread application of the Cre/loxP technology in mice is the cell-type-specific ("conditional") deletion of loxPflanked ("floxed") target genes. For this purpose, two mouse lines are required that work in combination: (1) a Cre "driver" line that expresses Cre (or the CreER ${ }^{\mathrm{T} 2}$ variant, see below) under control of a cell-type-specific promoter and (2) a mouse line, in which the gene of interest has been "floxed," mostly by homologous recombination in ES cells. In the floxed line, an essential part of the targeted gene is flanked by two equally oriented, 34 bp long loxP sites (these sequences are absent from the normal murine genome). The position of both loxP sites is chosen such that their presence does not interfere with normal gene expression, typically in an intronic position. After crossbreeding the two mouse lines, all Cre-expressing cells in the double-transgenic offspring (as defined by the cell-typespecific promoter/enhancer driving the Cre transgene) will, in principle, recombine the floxed target gene, leaving a single loxP site behind. In mice homozygous for the floxed gene, this leads to the irreversible inactivation of gene function in a cell-type-specific manner.

Since the first demonstration of a cell-type-specific gene knockout in living mice, the ablation of a ubiquitously expressed DNA polymerase selectively from T-cells [17], a long list of conditional mouse mutants has demonstrated the usefulness of this approach, including for oligodendroglial and myelin-related research. For

5' ATAACTTCGTATA-ATGTATGC-TATACGAAGTTAT 3'

Fig. 2 Sequence of a wild-type loxP site. Please note that the bases in the $8 \mathrm{bp}$ "spacer region" (except for the two in the middle) may differ in genetically engineered loxP variants 
1.3 Floxed Mice:

Modifying Target Genes by Introducing IoxP Sites example, by inactivation of two ubiquitously expressed enzymes, PTEN and mTOR, selectively in cells of the oligodendroglial lineage, we and others have identified the PI3K/AKT/mTOR pathway as a physiological regulator of myelin membrane growth [18-20].

The Cre-loxP technology can also be used to turn on (or to turn off) regular transgenes generated by pronuclear injection. This approach has been helpful in mouse models of diseases that are caused by the overexpression of genes or transgenes with gain-offunction mutations. For example, a cell-type-specific "turn-off" strategy has been used to selectively remove an entire loxP-flanked transgene (encoding a mutant form of superoxide dismutase-1, SOD1), which is ubiquitously expressed, from OPC in the CNS. In this mouse model of amyotrophic lateral sclerosis (ALS), the loss of SODI toxicity from OPC was sufficient to delay disease onset [21], proving the role of OLC in a neurodegenerative disease. For "turning on" transgenes, most often a floxed "stop" cassette is placed upstream of a transgene that prevents functional translation of the RNA transcript. However, once the stop cassette is excised by Cre-mediated recombination, transgene expression, driven by a ubiquitously active promoter, is induced (see for example [22]). Importantly, upon Cre recombination the mouse genome is irreversibly changed. Experimental systems, in which transgene expression is switched "on" or "off" in a reversible manner, e.g., by the tetracycline regulated transactivator system $[23,24]$, have been discussed elsewhere [25].

To generate mouse mutants with a Cre-modifiable target gene, essential regions of this gene need to be "floxed" in a way that the newly introduced loxP sequences do not interfere with gene regulation, mRNA splicing, or the protein coding region. Thus, loxP sites are typically placed into introns. However, also loxP insertions into $5^{\prime}$ or $3^{\prime}$ untranslated regions (UTRs) have been reported that did not interfere with wild-type-like expression of the target genes [26]. Since truncated proteins may still be functional or exert dominant-negative effects, floxing the first exon (s) of a gene with the ATG start codon is more likely to create a functional null allele. The generation of loxP-flanked alleles is commonly achieved by homologous recombination of a cloned genomic targeting construct that is transfected into embryonic stem cells (ESC) (Fig. 1). This "knock-in" strategy will be increasingly replaced by CRISPR/Cas9 nuclease guided gene editing of ESC or fertilized oocytes. Numerous protocols of Crispr/Cas9based genome editing have been published recently, including the generation of conditional alleles [27-29].

Homologous recombination requires the cloning of a genomic targeting vector with a selection cassette, most commonly a neomycin resistance gene. In contrast to a conventional gene targeting construct, this neo ${ }^{\mathrm{R}}$ cassette should be subsequently removed (also 
from intronic sites) because cryptic splice sites may affect gene expression and turn the floxed allele into a hypomorph or even into a null allele $[26,30]$. Thus, strategies have been developed to remove such a cassette, either in vitro or in vivo, once the correctly targeted allele has been identified. To do so, the selection cassette is often flanked by "frt" sites (for 'flip recognition target'), the palindromic 34 bp sequence for the yeast Flp ("flippase") recombinase [15]. Subsequent breeding to "Flp-deleter" mice [15, 31], in which Flp is active in germ cells or at the zygote stage, results in the removal of a selection cassette in vivo and in the germline [30], as schematically shown in Fig. 1.

Alternatively, the selection cassette in a targeting construct can be made removable by flanking it with a third loxP sequence. Recombination would require crossbreeding to Cre-deleter mice, such as EIIa-Cre $[32,33]$, aiming for partial recombination of specifically those loxP sites that flank the selection cassette.

We note that these intercrosses produce often mosaic offspring. Frt sites will not be necessarily recombined in all cells of a mouse that has inherited both the frt-targeted allele and the Flp-deleter allele [30]. Dependent on the recombination status of the germline cells, its offspring will (or will not) transmit the desired loxPflanked allele, i.e., the allele specifically lacking the frt-flanked selection cassette (see also Fig. 1). Likewise, crossing floxed mice with a mutant allele harboring 3 loxP sites to a Cre-deleter mouse, such as EIIa-Cre males, will produce mosaic offspring, in which the moderately efficient expression of Cre leads to different recombination events (i.e., recombination between $\operatorname{lox} \mathrm{Pl} / 2, \operatorname{loxP} 2 / 3, \operatorname{lox} \mathrm{Pl} / 3$, and no recombination at all) to a variable degree. Depending on the recombination status of the individual germ cells, further breeding of mosaic mice to wild-type mice may yield all four types of targeted alleles in the next generation, and those mice that inherited the desired "selection cassette-removed-only allele" can be chosen for establishing the intended floxed mouse line. For this reason, mosaic offspring and all mice in the subsequent generation(s) have to be carefully checked for the segregation of the different loxP-flanked alleles and for the loss of the Cre or Flp genes. This requires a PCR analysis of genomic DNA using different sets of primers designed to detect all possible recombination events (see Fig. I for frt-flanked selection cassettes and $[26,34,35]$ for the work flow of turning 3-loxP into 2-loxP mouse mutants).

The need for custom-made, self-designed floxed mutants has substantially decreased in recent years as a growing number of targeted ES cell clones and floxed mouse lines is made available to the scientific community by the International Knock-out Consortium (IKMC, www.knockoutmouse.org), which includes the European and the North American Conditional Mouse Mutagenesis Programs (EUCOMM, NorCOMM) [36]. In addition, more than 1270 floxed mouse strains are currently listed and made 


\subsection{Cre and Inducible CreER ${ }^{T}$ Mouse Lines for Oligodendrocyte Lineage Cells}

available by the Jackson Laboratory (https://www.jax.org/mousesearch). See Notes $\mathbf{1}$ and $\mathbf{2}$ for additional transgenic mice of relevance to study oligodendrocyte biology.

Many genes have been identified that are predominantly expressed in oligodendrocytes and/or their precursor cells. Based on their spatiotemporal expression profile, the corresponding Cre (or $\mathrm{CreER}^{\mathrm{T}}$, see below) driver lines can be categorized by their expression in OPC, mature oligodendrocytes, or the entire oligodendroglial cell lineage. For example, OPC are most often targeted with Cre expressed under control of the $\mathrm{Ng} 2$ or Pdgfr alpha regulatory region. Oligodendrocytes can be targeted by Cnp, Plpl, or Tmeml 0 promoter-driven Cre-transgenes, and the entire lineage can be targeted with Sox10-Cre driver lines (see Table 1). Most mouse lines are also listed online by the Network Glia (https:// www.networkglia.eu/tiermodelle) and by the Jackson Laboratory (https://www.jax.org/research-and-faculty/tools/cre-reposi tory), including purchasing options.

Oligodendrocytes in the CNS are of different spatial origin, which suggests some heterogeneity also with respect to gene expression, development, and adult function [54, 66, 67]. Moreover, cortical and subcortical oligodendrocyte defects have been associated with diseases of the CNS, including schizophrenia, depression, autism, and Alzheimer's disease [68]. Thus, it may be desirable to target oligodendroglial genes in cortical and subcortical oligodendrocytes and spare oligodendrocytes in brain areas essential for basic motor functions (cerebellum, spinal cord). We thus added also forebrain-specific Cre driver lines into Table 1, which can be used to target relevant oligodendroglial subsets, for example, when the target gene itself is expressed only in oligodendrocyte lineage cells, or if the targeted transgene (which shall be turned on or off) is driven by an OLC-specific promoter.

A better temporal control over Cre-mediated genomic recombination has been achieved with an inducible system, in which Cre is expressed as a chimeric fusion protein harboring the ligandbinding domain of a modified estrogen receptor that is activatable by the administration of tamoxifen. Specifically, Cre (when fused to the G521R-mutated hormone-binding domain of the human estrogen receptor) is still responsive to the synthetic estrogen receptor ligand 4-hydroxytamoxifen (4-OHT) but not to endogenous $17 \beta$-estradiol (E2) $[69,70]$. In the absence of tamoxifen, $\mathrm{CreER}^{\mathrm{T}}$ is sequestered in the cytosol by binding to a heat-shock protein (Hsp90) and cannot enter the nucleus. However, upon binding of Tamoxifen (the prodrug) or 4-OHT (the active metabolite), $\mathrm{CreER}^{\mathrm{T}}$ translocates into the nucleus and catalyzes recombination (Fig. 3). By this mechanism an extra level of temporal control is achieved in cell-type-specific gene targeting. The functionally improved version $\mathrm{CreER}^{\mathrm{T} 2}[71]$ is a triple mutant $\mathrm{G} 400 \mathrm{~V} /$ 


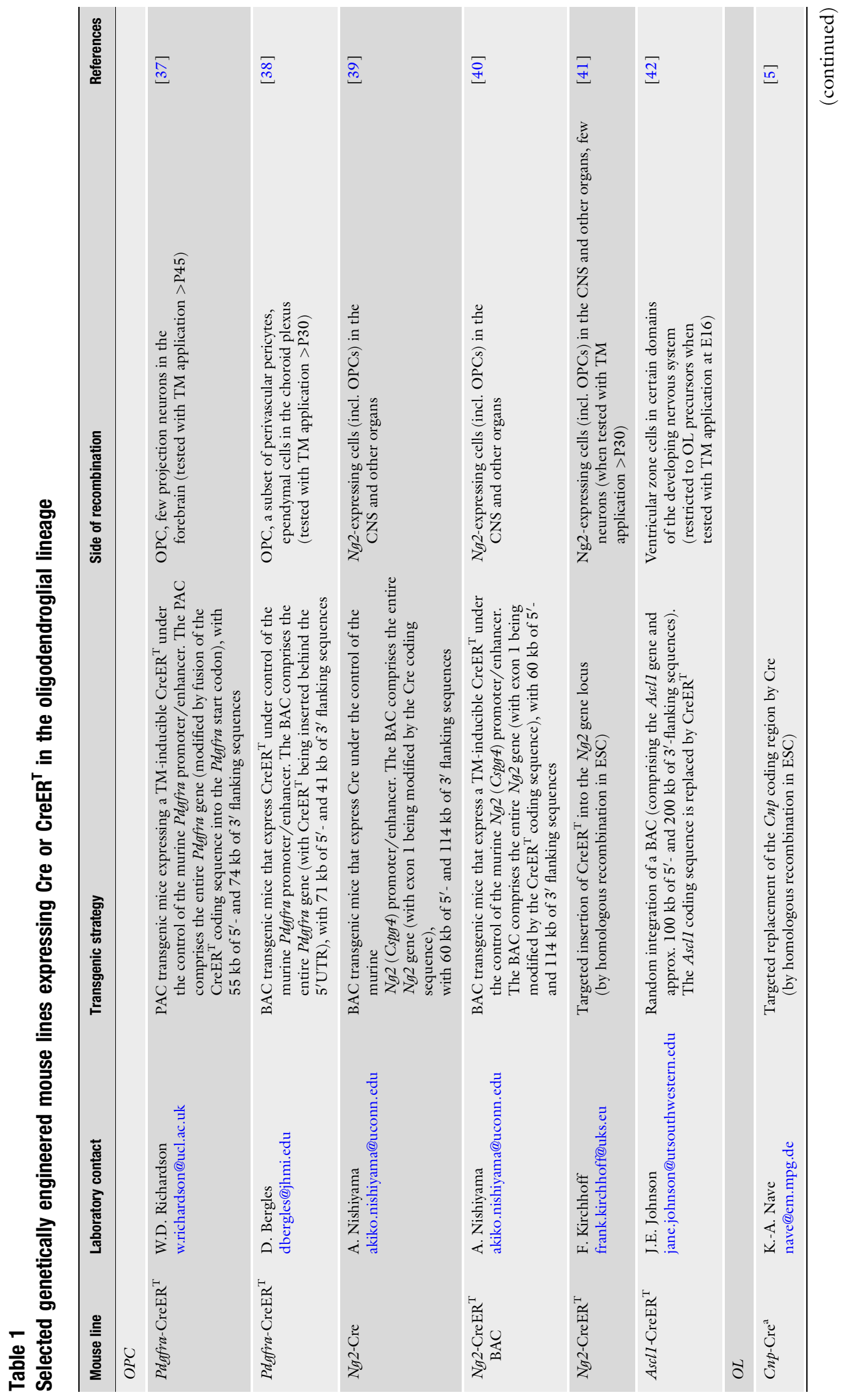




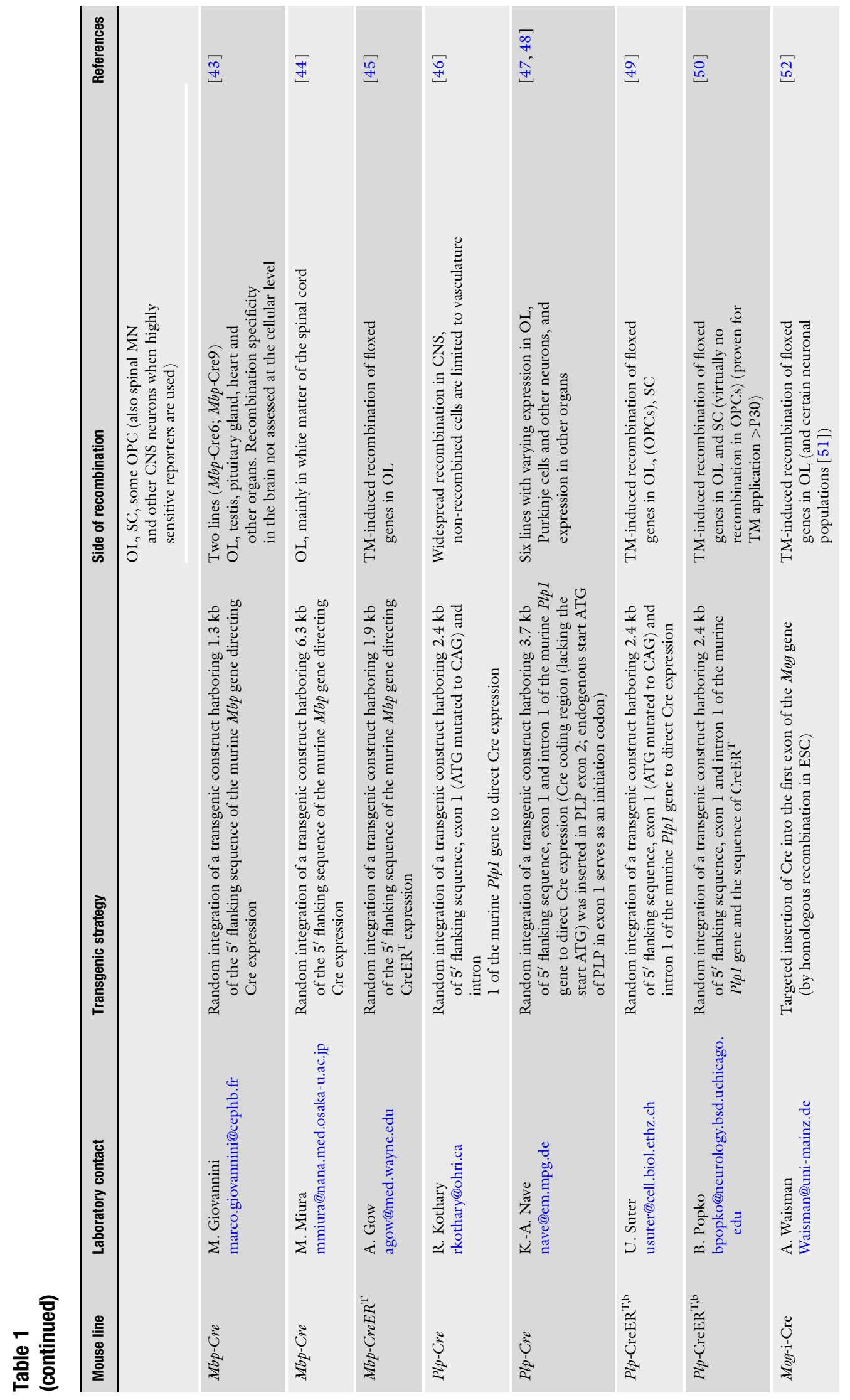




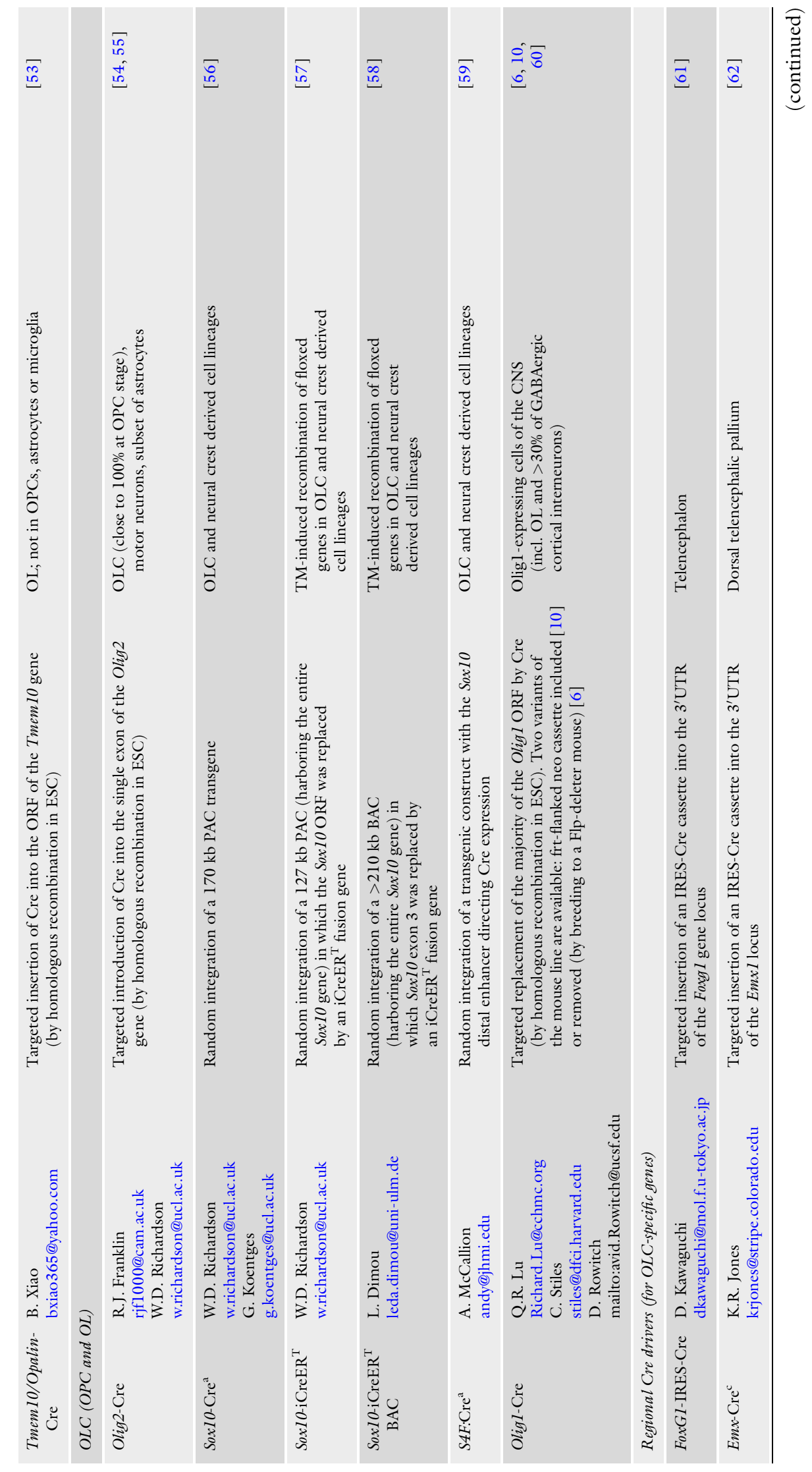




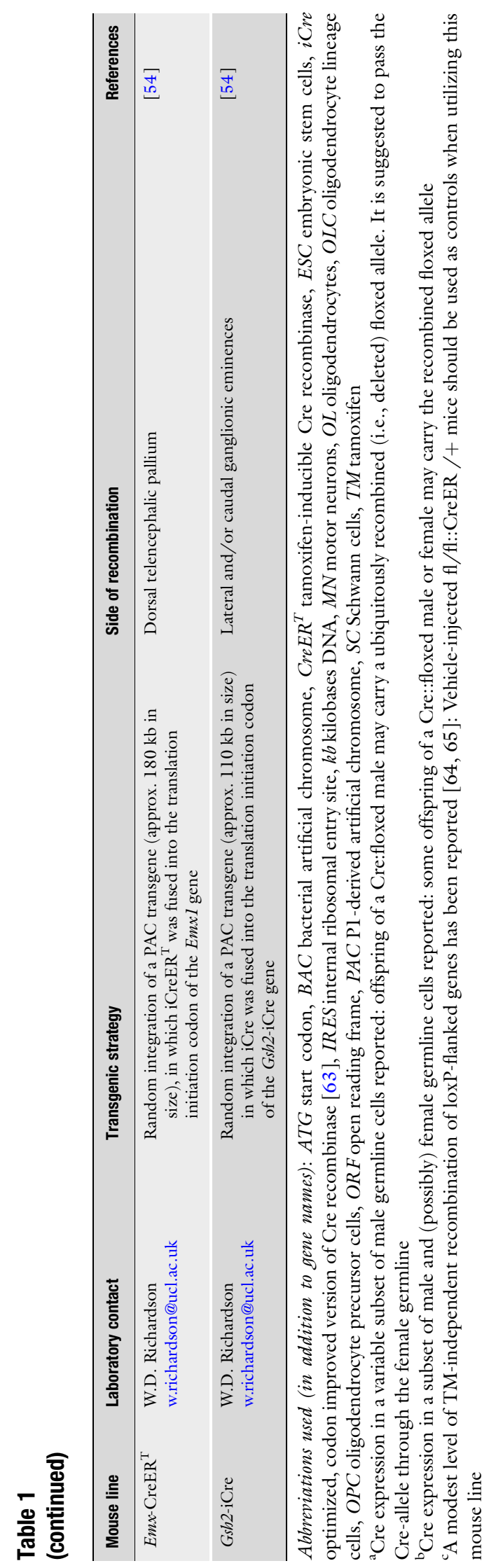




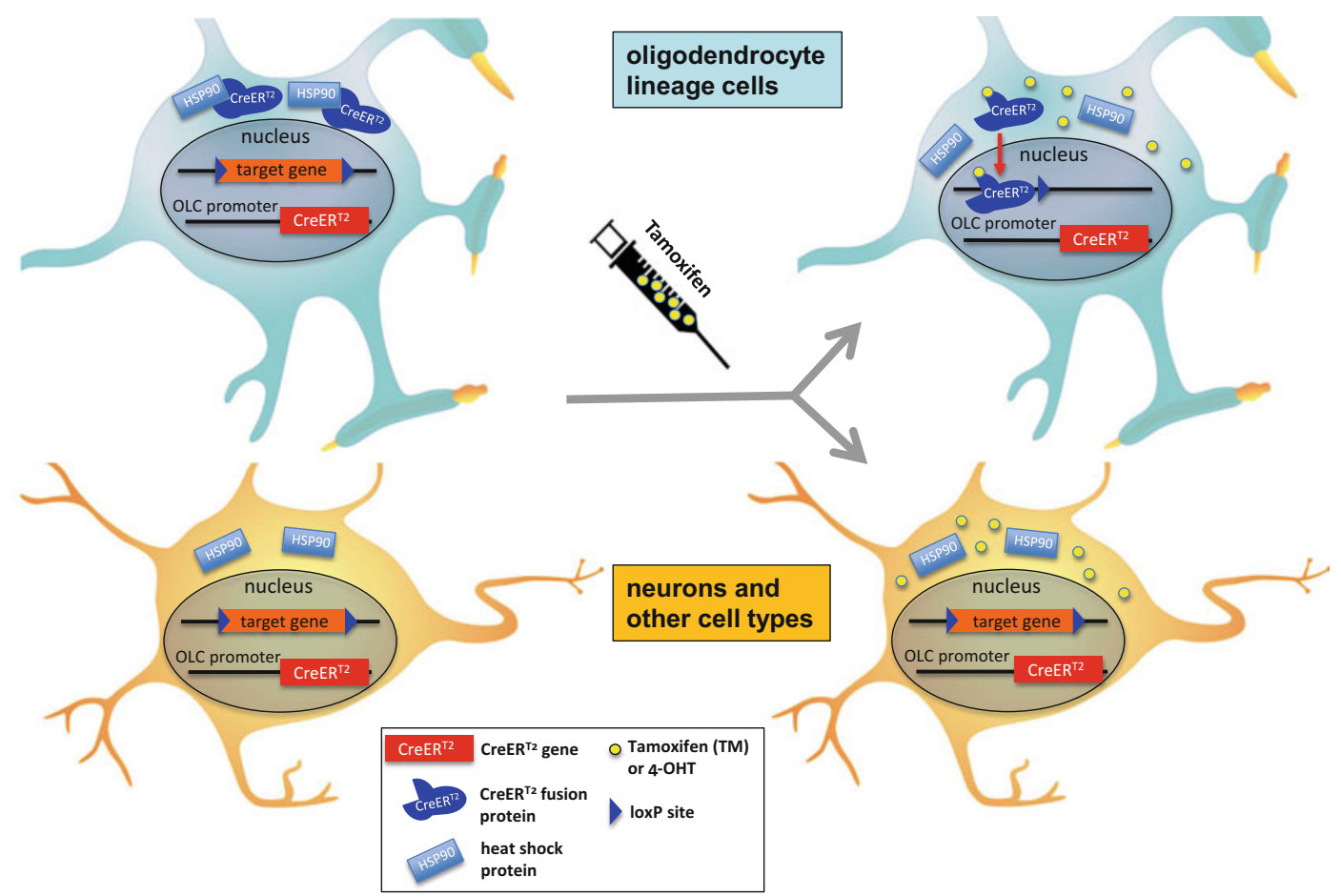

Fig. 3 Schematic depiction of the conditional inactivation of a loxP-flanked (floxed) target gene (orange) in oligodendrocyte lineage cells using Tamoxifen-dependent activation of $\mathrm{CreER}^{\mathrm{T} 2}$. Note that the $\mathrm{CreER}^{\mathrm{T2}}$ gene (red) is expressed only in oligodendrocytes (on top) but the encoded protein (blue) prevented from entering the cell nucleus by being bound to Hsp90, a heat-shock protein. Upon administration of tamoxifen (yellow), occupation of the hormone-binding site of $\mathrm{CreER}^{\mathrm{T2}}$ causes a conformational change and the release of Hsp90, followed by nuclear entry of CreER ${ }^{\mathrm{T2}}$ and genomic recombination

\subsection{Breeding Conditional Mouse Mutants}

M543A/L544A of the ligand-binding domain that exhibits decreased recombinase activity in the nonactivated state and increased efficacy upon tamoxifen binding. Today, it is the predominantly used variant for the generation of tamoxifen-inducible Cre driver lines (Table 1).

On average, and depending on strain, the life span of mice is about 2 years. Females become sexually mature at the age of $6-8$ weeks and remain fertile for about 6 months. During that time, they can give rise to approx. 2-4 litters of 5-10 pups each. With 19 days of gestation and 3 weeks until weaning (and routine genotyping), the generation time of mice is about 3 months. Males should be used for breeding not before 8 weeks of age and remain fertile for approximately 12 months. Breedings are ideally set up with 1 male and 2 female mice that are only separated $1-2$ days before delivery.

For an efficient and cost-saving breeding strategy, the first generation of mice, which are heterozygous for a floxed gene $\mathrm{X}$ (termed $\mathrm{X}^{\mathrm{fl} /+}$ in the following), should be intercrossed by brother/ 
sister matings and to a $\mathrm{Y}^{\mathrm{Cre} /+}$ (or $\mathrm{Y}^{\mathrm{CreER} /+}$ ) mouse that expresses Cre (or CreER ${ }^{\mathrm{T} 2}$ ) under the desired cell-type-specific promoter from gene "Y." By simple Mendelian rules, the crossbreeding of heterozygous $\mathrm{X}^{\mathrm{fl} /+}$ mice to each other (in the "F0 generation") will generate $25 \%$ homozygous $\mathrm{X}^{\mathrm{fl} / \mathrm{fl}}$ offspring in Fl. Breeding of the same $\mathrm{X}^{\mathrm{fl} /+}$ heterozygotes to the $\mathrm{Y}^{\mathrm{Cre} /+}\left(\right.$ or $\left.\mathrm{Y}^{\mathrm{CreER} /+}\right)$ driver mice will generate $25 \% \mathrm{X}^{\mathrm{fl} /+}:: \mathrm{Y}^{\mathrm{Cre} /+}\left(\right.$ or $\left.\mathrm{X}^{\mathrm{fl} /+}:: \mathrm{Y}^{\mathrm{CreER} /+}\right)$ offspring in $\mathrm{Fl}$ that are heterozygous for both mutant alleles. The subsequent mating of unaffected $\mathrm{X}^{\mathrm{fl} /+}:: \mathrm{Y}^{\mathrm{Cre} /+}\left(\right.$ or $\left.\mathrm{X}^{\mathrm{fl} /+}:: \mathrm{Y}^{\mathrm{CreER} /+}\right)$ mice (Fl) to the homozygous $\mathrm{X}^{\mathrm{fl} / \mathrm{fl}}$ mice (F1, also unaffected) will already produce a F2 generation, in which $25 \%$ of the mice are "mutants" and possibly phenotypically affected, i.e., homozygous for two floxed alleles and heterozygous for the Cre driver $\left(\mathrm{X}^{\mathrm{ll} / \mathrm{fl}}:: \mathrm{Y}^{\mathrm{Cr} /+}\right.$ or $\mathrm{X}^{\mathrm{fl} / \mathrm{fl}}:$ : $\mathrm{Y}^{\mathrm{CreER} /+}$ ). Another $25 \%$ of mice are "controls" that are homozygous for the floxed gene but harbor no Cre allele $\left(\mathrm{X}^{\mathrm{fl} / \mathrm{fl}}:: \mathrm{Y}^{+/+}\right)$. However, by maintaining these F2 mice as future parental animals and mating them to each other, the generation of experimental mice and controls becomes more efficient: conditional mutants $\left(\mathrm{X}^{\mathrm{fl} / \mathrm{fl}}:: \mathrm{Y}^{\mathrm{Cre} /+}\right.$ or $\mathrm{X}^{\mathrm{fl} / \mathrm{fl}}:$ : $\mathrm{Y}^{\mathrm{CreER} /+}$ ) and controls $\left(\mathrm{X}^{\mathrm{fl} / \mathrm{fl}}:: \mathrm{Y}^{+/+}\right)$will always be born in a $50 / 50$ ratio. This breeding strategy can generally be applied if a CreER ${ }^{\mathrm{T} 2}$ driver line is used, because the mutant animals $\left(\mathrm{X}^{\mathrm{fl} / \mathrm{fl}}:: \mathrm{Y}^{\mathrm{CreER} /+}\right)$ are not burdened prior to Tamoxifen injection (Fig. 4). Obviously, for constitutive Cre driver lines this efficient breeding strategy is only suitable if the mutants $\left(\mathrm{X}^{\mathrm{fl} / \mathrm{fl}}:: \mathrm{Y}^{\mathrm{Cre} /+}\right)$ are not burdened with a disabling phenotype or even infertile. In that case the parental $\mathrm{X}^{\mathrm{fl} / \mathrm{fl}}$ mice should be intercrossed with unaffected double heterozygotes $\left(\mathrm{X}^{\mathrm{fl} /+}:\right.$ : $\mathrm{Y}^{\mathrm{Cre} /+)}$, as suggested before for the generation of F2 mice.

The efficient breeding strategy will also not suffice if (1) Cre is a knock-in and haploinsufficiency of this locus matters, (2) when cytotoxic effects of Cre are suspected $[72,73]$ or $(3)$ when the conditional deletion of only one of the floxed target alleles is already of phenotypic relevance. In these cases additional breedings have to be included in order to generate control genotypes, such as $\mathrm{X}^{+/+}:$: $\mathrm{Y}^{\mathrm{Cre} /+}$ (for toxicity and haploinsufficiency of the Cre-expressing locus) or $\mathrm{X}^{\mathrm{fl} /+}:: \mathrm{Y}^{\mathrm{Cre} /+}\left(\mathrm{X}^{\mathrm{fl} /+}:: \mathrm{Y}^{\mathrm{CreER} /+}\right)$ (for haploinsufficiency of the target locus).

In the unlikely event that conditional mutants $\left(\mathrm{X}^{\mathrm{fl} / \mathrm{fl}}:: \mathrm{Y}^{\mathrm{Cre} /+}\right.$ or $\mathrm{X}^{\mathrm{fl} / \mathrm{fl}}:: \mathrm{Y}^{\mathrm{CreER} /+}$ ) are never born and embryonic lethality can be ruled out, one should consider that Cre and the floxed gene are located on the same chromosome. This can make it difficult, or virtually impossible, to obtain the required genotype. Here, using a different Cre driver line may be the simplest solution to the problem.

Floxed alleles can be easily converted to null alleles by crossbreeding to Cre-deleter strains, such as EIIa-Cre $[32,33]$ that recombine in the germline. Thus, two strategies for working with conditional mutants are followed by utilizing either homozygously floxed mice $\left(\mathrm{X}^{\mathrm{fl} / \mathrm{fl}}\right)$ or heterozygously floxed mice $\left(\mathrm{X}^{\mathrm{fl} /-}\right)$ on the null mutant background. Both strategies have advantages and 


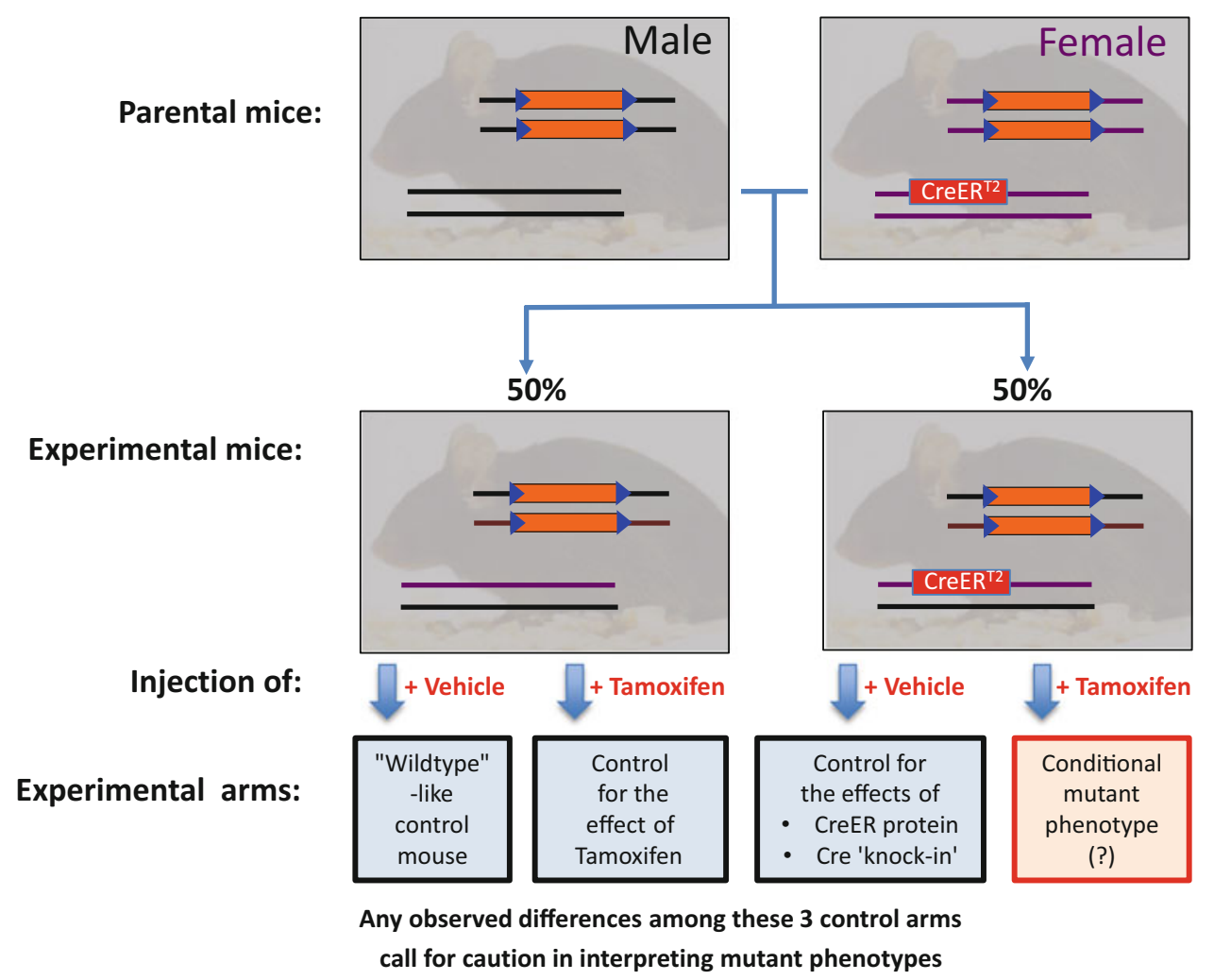

Fig. 4 Breeding scheme for the generation of conditional null mutants and controls. Having ensured that "floxed" mice are normally developed, the most convenient strategy is to generate and intercross parental animals of the genotypes $\mathrm{fl} / \mathrm{fl}::+/+$ and $\mathrm{fl} / \mathrm{fl}:: \mathrm{CreER}^{\mathrm{T} 2} /+$. This results in an equal number of offspring with the genotypes $\mathrm{fl} / \mathrm{fl}::+/+$ and $\mathrm{fl} / \mathrm{fl}:: \mathrm{CreER}^{\mathrm{T} 2} /+$. Injection of tamoxifen to the conditional mutants induces Cre-mediated recombination and thus cell-type-specific ablation of the gene of interest (orange frame). Experimental results from these animals should be carefully controlled by including three control conditions (black frames). First, vehicle treated fl/fl:: $\mathrm{CreER}^{\mathrm{T} 2} /+$ mice are used to control for effects of the Cre mutant allele, such as haploinsufficiency effects, Cre toxicity related issues or potential background recombination by non-induced Cre (in comparison to vehicle treated fl/fl:: $+/+$ controls). Second, tamoxifen-treated fl/fl:: $+/+$ animals without the Cre allele are used to determine the influence of Tamoxifen on the experimental paradigm

disadvantages. Since recombination of one allele is faster than of two, it may be more efficient to work on a heterozygous null mutant background, especially when Cre expression is low and/or transient. However, mice heterozygous for myelin genes can have relevant phenotypes $[74,75]$. Thus, phenotypes caused by haploinsufficiency of the target gene may mask the conditional full mutant phenotype.

It is worth considering that Cre expression can sometimes be ectopically activated in the early embryo, which can give rise to fully recombined target genes in the germline. This has been reported for Sox10-Cre males [56] and is also sporadically evident in Cnp-Cre male mice [5] (Fig. 5, Table 1). 
A

B

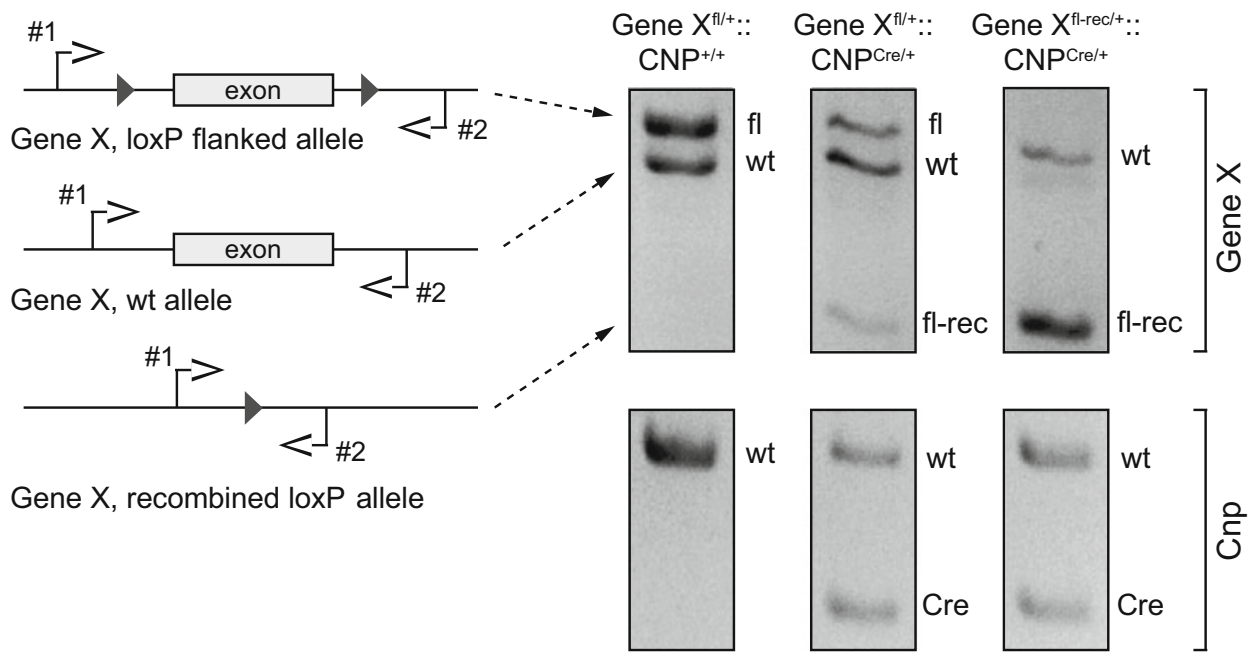

Fig. 5 Genomic PCR analysis of floxed mice by using a "two-Primer" strategy for the detection of short loxPflanked gene modifications. (a) Primers \#1 and \#2 are positioned $5^{\prime}$ and $3^{\prime}$ from an essential exon of gene " $X$ " that is flanked by loxP sites and detect the wild-type (+), the loxP-flanked (fl), and the recombined (fl-rec) allele. (b) Agarose gel electrophoresis on PCR products amplified from genomic tail tip DNA of mice with the

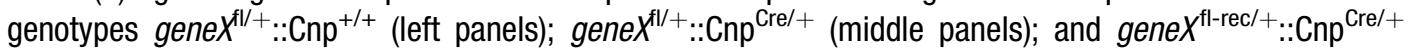
(right panels). The top row represents PCR products obtained from the targeted gene "X," the bottom row represents PCR products obtained from the Cnp allele. Please note that $\mathrm{Cnp}^{\text {Cre }}$ recombines in Schwann cells present in the tail tips. Thus, presence of the fl-rec allele is expected in all floxed mice that carry an additional $\mathrm{Cnp}^{\text {Cre }}$ allele (middle panels). In contrast, germline recombination, which fully converts the floxed allele into a ubiquitously present null allele, is indicated when (next to the wild-type allele) the floxed allele is not detectable, while the fl-rec product is present in high amounts (right panel). Please note that longer loxPflanked sequences require a "three primer strategy" with, for example, an additional antisense primer being included that is located in the targeted exon. Here, this primer in combination with primer \#1 would amplify a product from the wild-type and the floxed allele and primers \#1 and \#2 (more widely spaced from each other in this case) would only amplify a product after Cre-mediated recombination, since they would be spaced to much apart to amplify from the regular wild-type and the non-recombined floxed allele, respectively

\subsection{Treatment}

Regimen

for Tamoxifen-Induced

CreER $^{\text {T2}}$-Mediated

Recombination
Optimal protocols for tamoxifen-based $\mathrm{CreER}^{\mathrm{T} 2}$-mediated recombination have to be empirically determined because the recombination efficiency depends on different variables, such as (1) the specifics of the "floxed" gene, including the methylation/acetylation state of the floxed gene (which defines the accessibility of loxP sites) and the length of the floxed DNA segment, (2) the type of applied drug, i.e., tamoxifen or 4-OHT, (3) the route of administration (i.p. injection, gavage) and the frequency and length of treatment, and (4) the variable of age, sex, and genetic background of the recipient mouse. We suggest the protocol in Subheading 1.8 as a starting point to assess the efficiency of tamoxifen-induced $\mathrm{CreER}^{\mathrm{T} 2}$-mediated recombination in adult animals. An alternative 
is the application protocol proposed by the Jackson labs (https:// www.jax.org/research-and-faculty/tools/cre-repository/ tamoxifen).

\subsection{Utilizing Cre-Indicator Mice}

To assess cellular recombination specificity and efficiency of any Cre driver line, a plethora of "indicator" mice have been generated, in which (upon crossbreeding) Cre activates permanently the expression of reporter genes encoding fluorescent proteins or histochemically detectable enzymes. Note that the strength of the cellular signal does not reflect Cre expression, but rather the strength of the promoter that drives the reporter. Widely used are knock-ins into the constitutively active ROSA26 locus or transgenes expressed under control of ubiquitously active promoters, such as that of the chicken beta-actin gene. The Jackson laboratory alone lists more than 280 Cre "reporter" strains (https://www.jax.org/ mouse-search). The general idea of this strategy is that upon Cre-mediated excision of a loxP-flanked "stop"-cassette, cells will express easily identifiable reporter genes encoding, for example, LacZ $[76,77]$, alkaline phosphatase [78], or fluorescent proteins such as EGFP [79, 80], EYFP [81, 82], ECFP [82], ZsGreen [81], an EGFP-tandem version of dimeric DsRed (=tdsRed [83]), or tdTomato [81]. Since Cre-mediated recombination is irreversible, reporter genes become permanently activated in Cre-expressing cells and all their descendants. This allows this strategy to be applied for cell lineage tracing and fate mapping analyses, which have been heavily used in the analysis of oligodendrocytes and the spatial and temporal analysis of their precursor cells [37, 84-88] (see Note 3).

In dual reporter lines, the excised "stop" sequence is by itself a reporter gene, encoding a different fluorophore. Upon Cre recombination, this leads to a "switch" of color, including a variable time in which both reporters may be detectable. Weakly expressed fluorescent reporters can sometimes be made visible by more sensitive immunostaining. An X-Gal staining protocol to analyze the expression of beta-galactosidase (lacZ) as a reporter is given in Subheadings 2 and 3.

For myelin research, membrane-tagged reporters are of special interest. The $\operatorname{ROSA}^{\mathrm{mT} / \mathrm{mG}}$ reporter mouse line [89] expresses a ubiquitous cell membrane-localized tdTomato $(\mathrm{mT})$ protein but, upon Cre-mediated recombination, a membrane-localized EGFP $(\mathrm{mG})$. Similarly, ROSA ${ }^{\mathrm{nT} / \mathrm{nG}}$ reporter mice switch the same reporter proteins, which are directed to the cell nucleus [90]. Other reporter mice express fluorescent proteins that are targeted to membranes by a GPI anchor (CAG::GFP-GPI) or myristoylation (CAG::myr-Venus) [91]. Note that in myelinating glial cells, fluorescent proteins are too bulky to be wrapped into a compacted myelin sheath [92], but rather demarcate cytosolic tubes, paranodes, and other non-compacted regions of the myelin sheath. 
For the sparse-labeling of individual oligodendrocytes, any of the indicator mice discussed above can be used in combination with a $\mathrm{CreER}^{\mathrm{T} 2}$ driver line and a single low-dose injection (i.p.) of tamoxifen. Here, suggested doses range from 25 to $200 \mathrm{mg} / \mathrm{kg}$ [64]. Another application is the simultaneous activation of single reporter genes in multicolor fluorescent ("brain-bow") reporter mice that enable the single cell analysis of oligodendrocytes and their interactions in white matter tracts that are crowded with OLC $[64,93]$.

\subsection{Technical Caveats}

The Cre/loxP system is a powerful yet not unproblematic approach. One concern is that high-level expression of Cre itself may have off-target and thus unintended side effects on genomic integrity [94]. Thus, as a control group, the inclusion of mice with the Cre driver but without floxed alleles is highly recommended. Moreover, a randomly integrated Cre transgene may interfere with the expression of neighboring genes, a problem that can be reduced when only working with heterozygous Cre mice. While for targeted Cre "knock-in" mice the insertion site is well defined, haploinsufficiency may still occur and should be controlled for (by including non-Tamoxifen-induced $\mathrm{CreER}^{\mathrm{T} 2}$ mice or Cre mice without floxed alleles). We have, for example, replaced the coding region of Cnp by Cre, which has created a Cnp null allele, and heterozygous mice are fully normal and useful for the conditional deletion of floxed genes in oligodendrocytes. However, $\mathrm{Cnp}^{\mathrm{Cre} /+}$ mice develop a mild behavioral phenotype after 18 months of age with signs of neuroinflammation [74], which should be controlled for in any genetic experiment addressing brain aging. Expressing Cre downstream of an IRES (internal ribosomal entry site) may solve such problems [61].

Another problem, mostly affecting transgenic Cre lines, is the fact that promoters and regulatory elements are not always as celltype-specific in development as anticipated from gene expression in the adult. For example, PLPl is a highly cell-type-specifically expressed myelin protein, but 4 out of $6 \mathrm{Plpl-Cre}$ driver lines generated in our lab showed a variable degree of recombination in neuronal subpopulations $[47,48]$. This is most likely due to a low level of (transient) Cre expression already in neural stem cells. The same is true for Cnp-Cre mice, which are used to target oligodendrocytes, but also mark certain neuronal subtypes when used in combination with specific reporters [95, 96]. These off-target effects require a highly sensitive reporter line, in which the single target gene is very accessible and rapidly recombined. Thus, activation of a single reporter gene does not yet prove that any two floxed alleles of real target genes are likewise recombined. 
However, off-target recombination illustrates a Cre-specific problem: the enzyme is effective in trace amounts and any recombination is irreversible. On the other hand, Cre-mediated recombination is often not fully penetrant, i.e., less than $100 \%$ of the envisioned target cell population can be recombined. In this case, recombination efficiency is not necessarily limited by the Cre driver, but by the floxed alleles, whose chromatin state and accessibility for Cre may prohibit recombination in some but not all cells. What defines the epigenetic state of these target cells is unknown.

As mentioned above, for some OLC-specific Cre driver lines (not only those generated by pronuclear injection) at least sporadic Cre expression has been detected in the male germline (less frequent in female germline cells), and is likely underdiagnosed (or not reported) in other lines. When unaware of this, the resulting transmission of unexpected null alleles can severely perturb the experiment. A suitable PCR strategy to identify (1) wild-type, (2) floxed, and (3) fully recombined (fl-rec) alleles is presented in Fig. 5. Note that if Cre is also expressed in Schwann cells, the fully recombined allele can always be detected in the genomic DNA obtained from tail biopsies (independent of germline recombination).

In experiments with CreER ${ }^{\mathrm{T} 2}$ driver lines one should keep in mind that a low level of recombination may occur in the absence of tamoxifen, because the fusion protein is not $100 \%$ excluded from the nucleus. This has been reported, e.g., for two widely used Plpl$\mathrm{CreER}^{\mathrm{T} 2}$ lines $[64,65]$, and is possibly due to the strong activity of the Plpl promoter in combination with an easily accessible target gene.

Improvements of the Cre/loxP technique hold the potential of enhancing the cellular specificity of Cre or speeding up conditional mutagenesis. One is based on a "Split-Cre" complementation system, in which two inactive Split-Cre fragments are expressed under different promoters. Here, Cre recombinase activity is only regained when both halfmers are expressed in the same cell $[97,98]$.

Alternatively, it may suffice and be much faster than crossbreeding to delete genes in mature oligodendrocytes of homozygously floxed mice by stereotactically injecting Cre-expressing viruses into the brain. For oligodendrocytes, adeno-associated viruses (AAV) of various serotypes that express Cre (or CreER ${ }^{\mathrm{T} 2}$ ) under control of a $1.3 \mathrm{~kb}$ promoter fragment from the mouse Mbp gene are commercially available (Vector Biolabs). 


\section{Materials}

\section{$2.1 \quad X$-Gal Staining}

2.1.1 Avertin Solution

$2.1 .24 \%$

Paraformaldehyde (PFA)

in $0.1 \mathrm{M}$ Phosphate

Buffer Mix

2.1.3 X-Gal Solutions

\subsection{Extraction} of Genomic DNA and Genotyping of Cnp-Cre Mutant Mice

\subsection{Intraperitoneal Injection of Adult Mice with Tamoxifen}

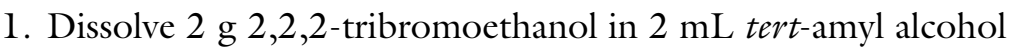
and add $96 \mathrm{~mL}$ of warm dd $\mathrm{H}_{2} \mathrm{O}\left(40{ }^{\circ} \mathrm{C}\right)$. Stir for $30 \mathrm{~min}$ on a magnetic stirrer.

2. Sterile filtrate through a $0.2 \mu \mathrm{m}$ filter.

3. Store in the dark at $4{ }^{\circ} \mathrm{C}$ for up to 4 weeks.

4. Use $200 \mu \mathrm{L}$ per $10 \mathrm{~g}$ of mouse weight.

1. $400 \mathrm{~mL} \mathrm{Na}_{2} \mathrm{HPO}_{4}(0.2 \mathrm{M})$.

2. $100 \mathrm{~mL} \mathrm{NaH}{ }_{2} \mathrm{PO}_{4}(0.2 \mathrm{M})$.

3. $100 \mathrm{~mL}$ Formol (37\%, filtered).

4. $400 \mathrm{~mL} \mathrm{ddH}_{2} \mathrm{O}$.

1. X-Gal Solution A: 0.01\% Sodium deoxycholate, 0.02\% 4-Nonylphenyl-polyethylene glycol, $2 \mathrm{mM} \mathrm{MgCl}_{2}, 5 \mathrm{mM} \mathrm{K} \mathrm{K}_{3}[\mathrm{Fe}$ $\left.(\mathrm{CN})_{6}\right], 5 \mathrm{mM} \mathrm{K}_{4}\left[\mathrm{Fe}(\mathrm{CN})_{6}\right] \mathrm{mix}$ and keep it the dark at room temperature.

2. X-Gal Solution B (X-Gal stock solution): dissolve $20 \mathrm{mg}$ 5 -bromo-4-chloro-3-indolyl- $\beta$-D-galactoside in $1 \mathrm{~mL}$ DMSO.

1. $10 \times$ Modified Gitschier Buffer (MGB): $6.7 \mathrm{~mL} 1 \mathrm{M}$ Tris- $\mathrm{HCl}$ $\mathrm{pH} \quad 8.8$ (f.c.: $670 \mathrm{mM}), \quad 1.66 \mathrm{~mL} \quad 1 \quad \mathrm{M} \quad\left(\mathrm{NH}_{4}\right)_{2} \mathrm{SO}_{4}$ (f.c. $166 \mathrm{mM}$ ), $650 \mu \mathrm{L} 1 \mathrm{M} \mathrm{MgCl}$ (f.c. $65 \mathrm{mM}$ ), add $\mathrm{ddH}_{2} 0$ to $10 \mathrm{~mL}$.

2. Proteinase $\mathrm{K}$ stock solution: $10 \mathrm{mg} / \mathrm{mL}$ (in $\mathrm{ddH}_{2} \mathrm{O}$ ).

3. Triton X-100 diluted 1:10 in PCR grade $\mathrm{ddH}_{2} \mathrm{O}$.

1. Tamoxifen.

2. Corn Oil.

3. Ethanol.

4. $1 \mathrm{~mL}$ syringe graded in $100 \mu \mathrm{L}$ intervals.

5. 22-27 gauge needle.

6. Sharp container.

7. Chemical fume hood or biological safety cabinet.

8. Tissue lyser.

\section{Methods}

\subsection{X-Gal Staining}

1. Anesthetize mouse with Avertin-solution.

2. Perfuse mice through the left ventricle with $15 \mathrm{~mL}$ of Hank's balanced salt solution, followed by $50 \mathrm{~mL}$ of $4 \%$ paraformaldehyde in PBS. 


\subsection{Extraction of Genomic DNA and Genotyping PCR for Cnp-Cre Mutant Mice}

\subsubsection{DNA Extraction}

Quick DNA Prep Protocol

3.2.2 Standard-PCRProtocol for Genotyping Cnp-Cre Mice
3. Post-fix brain and/or spinal cord in $4 \%$ paraformaldehyde for $2 \mathrm{~h}$.

4. Section in phosphate-buffered saline (PBS) on a vibratome at 20-200 $\mu \mathrm{m}$.

5. Incubate sections in freshly prepared X-gal solution $(600 \mu \mathrm{L}$ of solution "B" added to $10 \mathrm{~mL}$ solution "A") in a humidified chamber (cell culture incubator) at $37^{\circ} \mathrm{C}$ for up to $16 \mathrm{~h}$ in the dark. Check for staining under a microscope.

6. Post-fix in $4 \%$ paraformaldehyde for $30 \mathrm{~min}$.

7. Wash sections two times in $1 \times$ PBS for $10 \mathrm{~min}$ each, and mount them in AquaPolymount or other suitable mounting media.

Extract genomic DNA from tail tips, mouths swaps, or ear punches by using a kit according to the manufacturer's protocols or by the following cheap "Quick DNA prep protocol."

All of the following steps are carried out in a 96 well plate using a shaking incubator and a water bath.

1. Prepare fresh $1 \times$ MGB (sufficient for 96 samples):

(a) $2.2 \mathrm{~mL} 10 \times \mathrm{MGB}$.

(b) $220 \mu \mathrm{L} \beta$-Mercaptoethanol (final conc. 1\%).

(c) $1.1 \mathrm{~mL} \mathrm{10 \%} \mathrm{Triton} \mathrm{X-100} \mathrm{(final} \mathrm{conc.} \mathrm{0.5 \% ).}$

(d) $18.48 \mathrm{~mL}$ PCR-grade $\mathrm{ddH}_{2} \mathrm{O}$.

2. Add $80 \mu \mathrm{L}$ of $1 \times$ MGB to each tail/ear-punch/mouth swap.

3. Add $20 \mu \mathrm{L}$ of proteinase $\mathrm{K}$ stock solution.

4. Digest tissues/cells for $1-2 \mathrm{~h}$ at $55^{\circ} \mathrm{C}$ while gently shaking.

5. Vortex samples briefly.

6. Quick spin down to collect all liquid.

7. Heat inactivate proteinase $\mathrm{K}$ by heating samples at $95^{\circ} \mathrm{C}$ for $5 \mathrm{~min}$.

(Important: traces of proteinase $\mathrm{K}$ suffice to inactivate Taq polymerase).

8. Spin down debris $(5-10 \mathrm{~min}$ at $2000 \times \mathrm{g})$.

9. Use $1-2 \mu \mathrm{L}$ of supernatant for PCR.

1. Prepare PCR reaction mix:

(a) $1 \mu \mathrm{L}$ DNA (100-400 ng).

(b) $0.5 \mu \mathrm{L}$ Puro3 s primer $(10 \mathrm{pmol} / \mu \mathrm{L})$. 


\subsection{Tamoxifen Induction Regimen}

(c) $0.5 \mu \mathrm{L}$ Cnp-E3 s primer $(10 \mathrm{pmol} / \mu \mathrm{L})$.

(d) $1.0 \mu \mathrm{L}$ Cnp-E as $(10 \mathrm{pmol} / \mu \mathrm{L})$.

(e) $2 \mu \mathrm{L} \mathrm{dNTP} \operatorname{mix}(2 \mathrm{mM})$.

(f) $2 \mu \mathrm{L} 10 \times \operatorname{RedTaq}$ buffer (Sigma).

(g) $1 \mu \mathrm{L}$ Red Taq polymerase ( $1 \mathrm{U} / \mu \mathrm{L}$, Sigma).

(h) Add $\mathrm{ddH}_{2} \mathrm{O}$.

(i) $20 \mu \mathrm{L}$.

2. Use Thermocycling program:
(a) $95^{\circ} \mathrm{C} 3 \mathrm{~min}$.
(b) $50{ }^{\circ} \mathrm{C} 30 \mathrm{~s}$.
(c) $72{ }^{\circ} \mathrm{C} 60 \mathrm{~s}$
(d) $95{ }^{\circ} \mathrm{C} 30 \mathrm{~s}$.
(e) Back to 2 for 35 cycles.
(f) $50{ }^{\circ} \mathrm{C} 60 \mathrm{~s}$.
(g) $72{ }^{\circ} \mathrm{C} 10 \mathrm{~min}$.
(h) Store at $4{ }^{\circ} \mathrm{C}$.

3. Separate PCR products on agarose gels for visualization. A 700 bp product from the wild-type allele is amplified by Cnp-E3 s $\left(5^{\prime}\right.$-GCCTTCAAACTGTCCATCTC- $\left.3^{\prime}\right)$ and Cnp-E as (5'-CCCAGCCCTTTTATTACCAC- $\left.3^{\prime}\right)$. The targeted Cre-allele is positively identified with primers puro3 s (5'-CATAGCCTGAAGAACGAGA-3') and Cnp-E as, yielding a 400 bp fragment.

1. In a chemical fume hood: dissolve tamoxifen in corn oil at a concentration of $10 \mathrm{mg} / \mathrm{mL}$ by high speed shaking (e.g., in a tissue lyser) at $37^{\circ} \mathrm{C}$ for $20 \mathrm{~min}$. Tamoxifen is not soluble in water.

2. A Tamoxifen solution is sensitive to UV light and, similar to crystalline Tamoxifen powder, must be stored in the dark (foilwrapped vial) at $4{ }^{\circ} \mathrm{C}$.

3. Sanitize injection site with $70 \%$ ethanol.

4. Administer Tamoxifen on $2 \times 5$ consecutive days (with a pause of 2 days in between) with one intraperitoneal injection a day. A standard dose of $100 \mu \mathrm{L}$ Tamoxifen solution contains $1 \mathrm{mg}$ Tamoxifen per adult mouse and day, and is effective to induce Cre-mediated recombination (see Notes 4-10). 
1. Several mouse lines have been generated that harbor floxed transgenes for experiments in optogenetics, i.e., the lightinduced opening or closing of ion channels in Cre-expressing cells [99]. Cre-dependent optogenetic tool-mice will aid, e.g., in studies on activity-dependent myelination [100] when expressed in genetically defined neuronal subsets. This includes principal neurons and parvalbumin-positive interneurons, both of which can be myelinated within the cortex of mice [101].

2. Other floxed indicator strains expressing effective sensors or effectors that may be useful for research on OLC include:

(a) Ai95D mice, expressing a Cre-dependent calcium indicator and fast variant of GCaMP6 [102].

(b) R26:lacZbpA(flox)DTA and R26:eGFP(flox)DTA mice that can be used for Cre-mediated cell ablation $[103,104]$.

(c) Floxed miRAP and floxed Ribo-Tag mice, which allow cell-type-specific profiling of miRNAs and translated mRNAs, respectively [105, 106].

(d) $\mathrm{PhAM}^{\text {floxed }}$ (photo-activatable mitochondria) mice expressing the photo-convertible fluorescent protein Dendra2 for labeling and analysis of mitochondria, their fusion/fission and transport [107].

(e) ROSA26-LSL-Cas9 mice for in vivo gene editing when combined with single guide RNAs and a source of Cre [108].

(f) ATP-sensor ATeam $1.03^{\text {YEMK }}$ mice to uncover energy deficits in axons with pathological myelination [114].

3. Recombination efficiencies of different reporter genes vary when tested in combination with the same Cre driver mouse (see for example [96]). Thus, reporter gene expression can be no proof that recombination of a floxed target gene has been efficient. Recombination must be additionally confirmed by other methods, such as PCR amplification of genomic DNA, Western blotting, in situ hybridization, or immunostaining.

Tamoxifen-induced recombination of target genes

4. Tamoxifen is a human carcinogen, teratogen, and mutagen. Review and follow the material safety data sheet and wear appropriate personal protective equipment. Pregnant women should not be exposed to or handle Tamoxifen in any form.

5. Tamoxifen is excreted by mice for up to $72 \mathrm{~h}$ after the last injection. Considered hazardous waste, bedding has to be 
changed and adequately disposed $72 \mathrm{~h}$ after the last tamoxifen administration.

6. Tamoxifen-treated mice should not be housed with untreated animals, because unintended recombination can occur by the contamination with traces of tamoxifen during activities such as licking, grooming, or coprophagy.

7. Tamoxifen is transmitted transplacentally and via lactation, which can lead to $\mathrm{CreER}^{\mathrm{T} 2}$-mediated recombination in embryos or early postnatal pups (see for example [49]).

8. Tamoxifen has considerable off-target effects that may confound the phenotypical analysis of floxed CreER ${ }^{\mathrm{T} 2}$ mutants [109]. It has, for example, been reported to impair consolidation and retrieval of memory in mice at doses relevant for inducing Cre-mediated recombination of floxed target genes [110]. Thus, inclusion of a tamoxifen-injected control group in the behavioral analysis of mice is highly recommended (Fig. 4).

9. Tamoxifen promotes the differentiation of OPC in vitro and in demyelinated lesions in vivo $[111,112]$ which again demonstrates the importance of including tamoxifen-injected experimental control groups (Fig. 4).

10. Ivermectin, a drug used to treat laboratory mice against ectoparasites, such as pinworms and fur mites, can cause unintended $\mathrm{CreER}^{\mathrm{T} 2}$-mediated recombination of loxP sites [113]. Here, oral ivermectin treatment of parental mice expressing $\mathrm{CreER}^{\mathrm{T} 2}$ under the control of an ubiquitin promoter and YFP under Rosa26 regulatory elements induced CreER ${ }^{\mathrm{T} 2}$ mediated recombination at loxP sites in T-cells of the offspring. Because of the blood brain barrier, the relevance of this finding to research on oligodendroglial cell lineages is yet unclear.

\section{Acknowledgments}

We thank Peter Brophy, Brian Popko, Dwight Bergles, Ueli Suter, Bill Richardson, Ori Peles, David Rowitch, and Richard Lu for personal communications on Cre driver lines, members of the Department of Neurogenetics for critical discussion, and Georg Wieser and Ulli Bode for help with the figures. Work in the authors' laboratories was supported by grants from the DFG (SPP 1757 to S.G. and K.A.N.) and by an European Research Council (ERC) advanced grant (to K.A.N.). 


\section{References}

1. Capecchi MR (2005) Gene targeting in mice: functional analysis of the mammalian genome for the twenty-first century. Nat Rev Genet 6 (6):507-512

2. Thomas KR, Capecchi MR (1987) Sitedirected mutagenesis by gene targeting in mouse embryo-derived stem cells. Cell 51 (3):503-512

3. Giese KP et al (1992) Mouse P0 gene disruption leads to hypomyelination, abnormal expression of recognition molecules, and degeneration of myelin and axons. Cell 71 (4):565-576

4. Klugmann M et al (1997) Assembly of CNS myelin in the absence of proteolipid protein. Neuron 18(1):59-70

5. Lappe-Siefke C et al (2003) Disruption of Cnpl uncouples oligodendroglial functions in axonal support and myelination. Nat Genet 33(3):366-374

6. Xin M et al (2005) Myelinogenesis and axonal recognition by oligodendrocytes in brain are uncoupled in Oligl-null mice. J Neurosci 25 (6):1354-1365

7. Emery B et al (2009) Myelin gene regulatory factor is a critical transcriptional regulator required for CNS myelination. Cell 138 (1):172-185

8. Skarnes WC et al (2011) A conditional knockout resource for the genome-wide study of mouse gene function. Nature 474 (7351):337-342

9. Goebbels $S$ et al (2006) Genetic targeting of principal neurons in neocortex and hippocampus of NEX-Cre mice. Genesis 44 (12):611-621

10. Lu QR et al (2002) Common developmental requirement for Olig function indicates a motor neuron/oligodendrocyte connection. Cell 109(1):75-86

11. Britsch $S$ et al (2001) The transcription factor Sox10 is a key regulator of peripheral glial development. Genes Dev 15(1):66-78

12. Van de Putte $\mathrm{T}$ et al (2003) Mice lacking ZFHXIB, the gene that codes for Smadinteracting protein- 1 , reveal a role for multiple neural crest cell defects in the etiology of Hirschsprung disease-mental retardation syndrome. Am J Hum Genet 72(2):465-470

13. Donohoe ME et al (1999) Targeted disruption of mouse Yin Yang 1 transcription factor results in peri-implantation lethality. Mol Cell Biol 19(10):7237-7244

14. Kotch LE et al (1999) Defective vascularization of HIF-lalpha-null embryos is not associated with VEGF deficiency but with mesenchymal cell death. Dev Biol 209 (2):254-267

15. Dymecki SM (1996) Flp recombinase promotes site-specific DNA recombination in embryonic stem cells and transgenic mice. Proc Natl Acad Sci U S A 93(12):6191-6196

16. Sauer B, Henderson N (1988) Site-specific DNA recombination in mammalian cells by the Cre recombinase of bacteriophage $\mathrm{Pl}$. Proc Natl Acad Sci U S A 85(14):5166-5170

17. Gu H et al (1994) Deletion of a DNA polymerase beta gene segment in T cells using cell type-specific gene targeting. Science 265 (5168):103-106

18. Goebbels $S$ et al (2010) Elevated phosphatidylinositol 3,4,5-trisphosphate in glia triggers cell-autonomous membrane wrapping and myelination. J Neurosci 30(26):8953-8964

19. Harrington EP et al (2010) Oligodendrocyte PTEN is required for myelin and axonal integrity, not remyelination. Ann Neurol 68 (5):703-716

20. Wahl SE et al (2014) Mammalian target of rapamycin promotes oligodendrocyte differentiation, initiation and extent of CNS myelination. J Neurosci 34(13):4453-4465

21. Kang SH et al (2013) Degeneration and impaired regeneration of gray matter oligodendrocytes in amyotrophic lateral sclerosis. Nat Neurosci 16(5):571-579

22. LoPresti P (2015) Inducible expression of a truncated form of tau in oligodendrocytes elicits gait abnormalities and a decrease in myelin: implications for selective CNS degenerative diseases. Neurochem Res 40 (11):2188-2199

23. Gossen M, Bujard H (1992) Tight control of gene expression in mammalian cells by tetracycline-responsive promoters. Proc Natl Acad Sci U S A 89(12):5547-5551

24. Gossen $\mathrm{M}$ et al (1995) Transcriptional activation by tetracyclines in mammalian cells. Science 268(5218):1766-1769

25. Schonig K, Freundlieb S, Gossen M (2013) Tet-transgenic rodents: a comprehensive, up-to date database. Transgenic Res 22 (2):251-254

26. Goebbels $S$ et al (2005) Cre/loxP-mediated inactivation of the bHLH transcription factor gene NeuroD/BETA2. Genesis 42 (4):247-252

27. Nakagawa Y et al (2016) Ultra-superovulation for the CRISPR-Cas9-mediated production of gene-knockout, single-amino-acid- 
substituted, and floxed mice. Biol Open 5 (8):1142-1148

28. Quadros RM et al (2017) Easi-CRISPR: a robust method for one-step generation of mice carrying conditional and insertion alleles using long ssDNA donors and CRISPR ribonucleoproteins. Genome Biol 18(1):92

29. Yang H, Wang H, Jaenisch R (2014) Generating genetically modified mice using CRISPR/Cas-mediated genome engineering. Nat Protoc 9(8):1956-1968

30. Meyers EN, Lewandoski M, Martin GR (1998) An Fgf8 mutant allelic series generated by Cre- and Flp-mediated recombination. Nat Genet 18(2):136-141

31. Farley FW et al (2000) Widespread recombinase expression using FLPeR (flipper) mice. Genesis 28(3-4):106-110

32. Holzenberger M et al (2000) Cre-mediated germline mosaicism: a method allowing rapid generation of several alleles of a target gene. Nucleic Acids Res 28(21):E92

33. Lakso M et al (1996) Efficient in vivo manipulation of mouse genomic sequences at the zygote stage. Proc Natl Acad Sci U S A 93 (12):5860-5865

34. Umans L et al (2003) Generation of a floxed allele of Smad5 for cre-mediated conditional knockout in the mouse. Genesis 37(1):5-11

35. Xu X et al (2001) Direct removal in the mouse of a floxed neo gene from a three-loxP conditional knockout allele by two novel approaches. Genesis 30(1):1-6

36. Ringwald $M$ et al (2011) The IKMC web portal: a central point of entry to data and resources from the International Knockout Mouse Consortium. Nucleic Acids Res 39 (Database issue):D849-D855

37. Rivers LE et al (2008) PDGFRA/NG2 glia generate myelinating oligodendrocytes and piriform projection neurons in adult mice. Nat Neurosci 11(12):1392-1401

38. Kang SH et al (2010) NG2+ CNS glial progenitors remain committed to the oligodendrocyte lineage in postnatal life and following neurodegeneration. Neuron 68(4):668-681

39. Zhu X, Bergles DE, Nishiyama A (2008) NG2 cells generate both oligodendrocytes and gray matter astrocytes. Development 135 (1):145-157

40. Zhu X et al (2011) Age-dependent fate and lineage restriction of single NG2 cells. Development 138(4):745-753

41. Huang W et al (2014) Novel NG2-CreERT2 knock-in mice demonstrate heterogeneous differentiation potential of NG2 glia during development. Glia 62(6):896-913
42. Battiste J et al (2007) Ascll defines sequentially generated lineage-restricted neuronal and oligodendrocyte precursor cells in the spinal cord. Development 134(2):285-293

43. Niwa-Kawakita $M$ et al (2000) Targeted expression of Cre recombinase to myelinating cells of the central nervous system in transgenic mice. Genesis 26(2):127-129

44. Hisahara $S$ et al (2000) Targeted expression of baculovirus p35 caspase inhibitor in oligodendrocytes protects mice against autoimmunemediated demyelination. EMBO J 19 (3):341-348

45. Gow A (2011) Using temporal genetic switches to synchronize the unfolded protein response in cell populations in vivo. Methods Enzymol 491:143-161

46. Michalski JP et al (2011) The proteolipid protein promoter drives expression outside of the oligodendrocyte lineage during embryonic and early postnatal development. PLoS One 6(5):e19772

47. Delaunay D et al (2008) Early neuronal and glial fate restriction of embryonic neural stem cells. J Neurosci 28(10):2551-2562

48. Delaunay D et al (2009) Genetic tracing of subpopulation neurons in the prethalamus of mice (Mus musculus). J Comp Neurol 512 (1):74-83

49. Leone DP et al (2003) Tamoxifen-inducible glia-specific Cre mice for somatic mutagenesis in oligodendrocytes and Schwann cells. Mol Cell Neurosci 22(4):430-440

50. Doerflinger NH, Macklin WB, Popko B (2003) Inducible site-specific recombination in myelinating cells. Genesis 35(1):63-72

51. Fruhbeis C et al (2013) Neurotransmittertriggered transfer of exosomes mediates oligodendrocyte-neuron communication. PLoS Biol 11(7):el001604

52. Hovelmeyer $\mathrm{N}$ et al (2005) Apoptosis of oligodendrocytes via Fas and TNF-Rl is a key event in the induction of experimental autoimmune encephalomyelitis. J Immunol 175 (9):5875-5884

53. Zou Y et al (2014) Oligodendrocyte precursor cell-intrinsic effect of Rhebl controls differentiation and mediates mTORCldependent myelination in brain. J Neurosci 34(47):15764-15778

54. Kessaris N et al (2006) Competing waves of oligodendrocytes in the forebrain and postnatal elimination of an embryonic lineage. Nat Neurosci 9(2):173-179

55. Zawadzka M et al (2010) CNS-resident glial progenitor/stem cells produce Schwann cells as well as oligodendrocytes during repair of 
CNS demyelination. Cell Stem Cell 6 (6):578-590

56. Matsuoka T et al (2005) Neural crest origins of the neck and shoulder. Nature 436 (7049):347-355

57. McKenzie IA et al (2014) Motor skill learning requires active central myelination. Science 346(6207):318-322

58. Simon C et al (2012) Soxl0-iCreERT2: a mouse line to inducibly trace the neural crest and oligodendrocyte lineage. Genesis 50 (6):506-515

59. Stine ZE et al (2009) Oligodendroglial and pan-neural crest expression of Cre recombinase directed by Sox 10 enhancer. Genesis 47 (11):765-770

60. Silbereis JC et al (2014) Oligl function is required to repress $\mathrm{dlxl} / 2$ and interneuron production in Mammalian brain. Neuron 81 (3):574-587

61. Kawaguchi D et al (2016) Generation and analysis of an improved Foxgl-IRES-Cre driver mouse line. Dev Biol 412(1):139-147

62. Gorski JA et al (2002) Cortical excitatory neurons and glia, but not GABAergic neurons, are produced in the Emxl-expressing lineage. J Neurosci 22(15):6309-6314

63. Shimshek DR et al (2002) Codon-improved Cre recombinase (iCre) expression in the mouse. Genesis 32(1):19-26

64. Dumas L et al (2015) Multicolor analysis of oligodendrocyte morphology, interactions, and development with Brainbow. Glia 63 (4):699-717

65. Traka M et al (2016) Oligodendrocyte death results in immune-mediated CNS demyelination. Nat Neurosci 19(1):65-74

66. Crawford AH et al (2016) Developmental origin of oligodendrocyte lineage cells determines response to demyelination and susceptibility to age-associated functional decline. Cell Rep 15:761-773

67. Tripathi RB et al (2011) Dorsally and ventrally derived oligodendrocytes have similar electrical properties but myelinate preferred tracts. J Neurosci 31(18):6809-6819

68. Nave KA, Ehrenreich H (2014) Myelination and oligodendrocyte functions in psychiatric diseases. JAMA Psychiat 71(5):582-584

69. Brocard J et al (1997) Spatio-temporally controlled site-specific somatic mutagenesis in the mouse. Proc Natl Acad Sci U S A 94 (26):14559-14563

70. Feil R et al (1996) Ligand-activated site-specific recombination in mice. Proc Natl Acad Sci U S A 93(20):10887-10890
71. Feil R et al (1997) Regulation of Cre recombinase activity by mutated estrogen receptor ligand-binding domains. Biochem Biophys Res Commun 237(3):752-757

72. Forni PE et al (2006) High levels of Cre expression in neuronal progenitors cause defects in brain development leading to microencephaly and hydrocephaly. J Neurosci 26(37):9593-9602

73. Qiu L, Rivera-Perez JA, Xu Z (2011) A non-specific effect associated with conditional transgene expression based on Cre-loxP strategy in mice. PLoS One 6(5):el8778

74. Hagemeyer $\mathrm{N}$ et al (2012) A myelin gene causative of a catatonia-depression syndrome upon aging. EMBO Mol Med 4(6):528-539

75. Poggi G et al (2016) Cortical network dysfunction caused by a subtle defect of myelination. Glia 64(11):2025-2040

76. Akagi K et al (1997) Cre-mediated somatic site-specific recombination in mice. Nucleic Acids Res 25(9):1766-1773

77. Soriano P (1999) Generalized lacZ expression with the ROSA26 Cre reporter strain. Nat Genet 21(1):70-71

78. Lobe CG et al (1999) Z/AP, a double reporter for cre-mediated recombination. Dev Biol 208(2):281-292

79. De Gasperi R et al (2008) The IRG mouse: a two-color fluorescent reporter for assessing Cre-mediated recombination and imaging complex cellular relationships in situ. Genesis 46(6):308-317

80. Hartwich H, Satheesh SV, Nothwang HG (2012) A pink mouse reports the switch from red to green fluorescence upon Cre-mediated recombination. BMC Res Notes 5:296

81. Madisen L et al (2010) A robust and highthroughput Cre reporting and characterization system for the whole mouse brain. Nat Neurosci 13(1):133-140

82. Srinivas $S$ et al (2001) Cre reporter strains produced by targeted insertion of EYFP and ECFP into the ROSA26 locus. BMC Dev Biol $1: 4$

83. Hasegawa Y et al (2013) Novel ROSA26 Cre-reporter knock-in C57BL/6N mice exhibiting green emission before and red emission after Cre-mediated recombination. Exp Anim 62(4):295-304

84. Clarke LE et al (2012) Properties and fate of oligodendrocyte progenitor cells in the corpus callosum, motor cortex, and piriform cortex of the mouse. J Neurosci 32 (24):8173-8185 
85. Dimou L et al (2008) Progeny of Olig2expressing progenitors in the gray and white matter of the adult mouse cerebral cortex. J Neurosci 28(41):10434-10442

86. Guo F et al (2010) Pyramidal neurons are generated from oligodendroglial progenitor cells in adult piriform cortex. J Neurosci 30 (36):12036-12049

87. Robins SC et al (2013) Evidence for NG2-glia derived, adult-born functional neurons in the hypothalamus. PLoS One 8(10):e78236

88. Tsoa RW et al (2014) Spatiotemporally different origins of NG2 progenitors produce cortical interneurons versus glia in the mammalian forebrain. Proc Natl Acad Sci U S A 111(20):7444-7449

89. Muzumdar MD et al (2007) A global doublefluorescent Cre reporter mouse. Genesis 45 (9):593-605

90. Prigge JR et al (2013) Nuclear doublefluorescent reporter for in vivo and ex vivo analyses of biological transitions in mouse nuclei. Mamm Genome 24:389-399

91. Rhee JM et al (2006) In vivo imaging and differential localization of lipid-modified GFP-variant fusions in embryonic stem cells and mice. Genesis 44(4):202-218

92. Aggarwal S et al (2011) A size barrier limits protein diffusion at the cell surface to generate lipid-rich myelin-membrane sheets. Dev Cell $21(3): 445-456$

93. Amitai-Lange A et al (2015) A method for lineage tracing of corneal cells using multicolor fluorescent reporter mice. J Vis Exp (106):e53370

94. Janbandhu VC, Moik D, Fassler R (2014) Cre recombinase induces DNA damage and tetraploidy in the absence of loxP sites. Cell Cycle 13(3):462-470

95. Genoud S et al (2002) Notchl control of oligodendrocyte differentiation in the spinal cord. J Cell Biol 158(4):709-718

96. Tognatta R et al (2017) Transient Cnp expression by early progenitors causes CreLox-based reporter lines to map profoundly different fates. Glia 65(2):342-359

97. Hirrlinger J et al (2009) Split-CreERT2: temporal control of DNA recombination mediated by split-Cre protein fragment complementation. PLoS One 4(12):e8354

98. Hirrlinger J et al (2009) Split-cre complementation indicates coincident activity of different genes in vivo. PLoS One 4(1):e4286

99. Madisen L et al (2012) A toolbox of Cre-dependent optogenetic transgenic mice for light-induced activation and silencing. Nat Neurosci 15(5):793-802

100. Gibson EM et al (2014) Neuronal activity promotes oligodendrogenesis and adaptive myelination in the mammalian brain. Science 344(6183):1252304

101. Micheva KD et al (2016) A large fraction of neocortical myelin ensheathes axons of local inhibitory neurons. Elife 5:e15784

102. Madisen L et al (2015) Transgenic mice for intersectional targeting of neural sensors and effectors with high specificity and performance. Neuron 85(5):942-958

103. Brockschnieder D et al (2006) An improved mouse line for Cre-induced cell ablation due to diphtheria toxin $\mathrm{A}$, expressed from the Rosa26 locus. Genesis 44(7):322-327

104. Ivanova A et al (2005) In vivo genetic ablation by Cre-mediated expression of diphtheria toxin fragment A. Genesis 43(3):129-135

105. He M et al (2012) Cell-type-based analysis of microRNA profiles in the mouse brain. Neuron $73(1): 35-48$

106. Sanz E et al (2009) Cell-type-specific isolation of ribosome-associated mRNA from complex tissues. Proc Natl Acad Sci U S A 106(33):13939-13944

107. Pham AH, McCaffery JM, Chan DC (2012) Mouse lines with photo-activatable mitochondria to study mitochondrial dynamics. Genesis 50(11):833-843

108. Platt RJ et al (2014) CRISPR-Cas9 knockin mice for genome editing and cancer modeling. Cell 159(2):440-455

109. Jardi F et al (2017) A shortened tamoxifen induction scheme to induce CreER recombinase without side effects on the male mouse skeleton. Mol Cell Endocrinol 452:57-63

110. Chen D et al (2002) Tamoxifen and toremifene cause impairment of learning and memory function in mice. Pharmacol Biochem Behav 71(1-2):269-276

111. Barratt HE et al (2016) Tamoxifen promotes differentiation of oligodendrocyte progenitors in vitro. Neuroscience 319:146-154

112. Gonzalez GA et al (2016) Tamoxifen accelerates the repair of demyelinated lesions in the central nervous system. Sci Rep 6:31599

113. Corbo-Rodgers E et al (2012) Oral ivermectin as an unexpected initiator of CreT2mediated deletion in $\mathrm{T}$ cells. Nat Immunol 13(3):197-198

114. Trevisol et al (2017) Monitoring ATP dynamics in electrically active white matter tracts. eLife 6. pii: e24241 